\title{
Seed yield of mungbean as affected by variety and plant spacing in Kharif-I season
}

\author{
M.H. Kabir ${ }^{1}$ and M.A.R. Sarkar \\ Department of Agronomy, Bangladesh Agricultural University, Mymensingh-2202, Bangladesh \\ ${ }^{1}$ Deputy Director, Bangla Academy, Dhaka
}

\begin{abstract}
An experiment was carried out to study the effect of variety and planting density on the yield of mungbean in Kharif-I season (February to June) of 2003. The experiment comprised five varieties viz. BARIMung-2, BARIMung-3, BARIMung-4, BARIMung-5 and BINAMung-2 and three spacing of planting viz. $30 \mathrm{~cm} \times 10 \mathrm{~cm}, 20 \mathrm{~cm} \times 20 \mathrm{~cm}$ and $40 \mathrm{~cm} \times 30 \mathrm{~cm}$. The experiment was laid out in a randomized complete block design with three replications. It was observed that BARIMung-2 produced the highest seed yield and BINAMung-2 did the lowest. Plant spacing of $30 \mathrm{~cm} \times 10 \mathrm{~cm}$ produced the highest seed yield of mungbean while $40 \mathrm{~cm} \times 30 \mathrm{~cm}$ spacing produced the lowest seed yield. BARIMung-2 planted at a spacing of $30 \mathrm{~cm} \times 10 \mathrm{~cm}$ gave the maximum seed yield.
\end{abstract}

Keywords: Mungbean, Variety, Plant spacing, Yield

\section{Introduction}

Mungbean (Vigna radiata L.) is an important pulse crop of Bangladesh which contains high graded vegetable proteins and satisfactory level of minerals and vitamins. Mungbean may be the first choice of farmers due to its good taste, easy digestibility, better palatability and acceptable market price. Among the pulses area, only $8.10 \%$ lands are used for the cultivation of mungbean (Kabir, 2001). According to World Health Organization (WHO), per capita per day requirement of pulse is $45 \mathrm{~g}$. But in Bangladesh, only $12 \mathrm{~g}$ pulse is available per capita per day. About 6.01 million tons of pulse is required to meet the present per capita requirement of our country (BARI, 1998). The modern varieties of mungbean usually produce higher seed yield. Mungbean variety MB-55 produced higher seed yield than MB-63 at all three locations of Bangladesh (Ahmed et al., 1987). The yield of recently developed mungbean varieties Kanti, Mubarik and BINAMung-1 ranges from 1.0 to 1.2, 0.8 to 1.0 and 0.8 to $1.0 \mathrm{t} \mathrm{ha}^{-1}$, respectively (ICRISAT, 1991). Seed yield and yield components of mungbean are markedly influenced by planting density. The farmers usually grow mungbean without maintaining proper planting density. They hesitate to grow mungbean in rows, although row planting facilitates easy intercultural operations resulting in higher yield (BARI, 1997). Row planting with appropriate planting density can help ensure optimum plant population unit ${ }^{-1}$ area of mungbean thereby increasing the yield (BARI, 1998). Mungbean grown at a density of 33 plant $\mathrm{m}^{-2}$ produced higher yield (Thakuria and Saharia, 1990). Optimum plant density for higher yield of mungbean were 50 to 60 plants $\mathrm{m}^{-2}$ (Mimber, 1993) and 30 to 40 plants $\mathrm{m}^{-2}$ (BARI, 1998). The highest yield of mungbean was observed from a density of 33 plants $\mathrm{m}^{-2}$ (Haque, 1995). The present study was, therefore, undertaken to find out the relative yielding ability of five varieties of mungbean in Kharif-I season under variable spacing of planting.

\section{Materials and Methods}

The experiment was conducted at the Agronomy Field Laboratory, Bangladesh Agricultural University, Mymensingh, during the period from February to June (Kharif-I season), 2002. The soil of experimental plot was sitly loam with $\mathrm{pH} 6.7$, organic matter $1.55 \%$, total nitrogen (N) $0.055 \%$, available phosphorus (P) $12 \mathrm{ppm}$, available sulphur (S) $16 \mathrm{ppm}$ and exchangeable potassium (K) 0.38 me $100^{-1} \mathrm{~g}$ soil. The experiment comprised five varieties of 
mungbean viz. (i) BARIMung-2, (ii) BARIMung-3, (iii) BARIMung-4, (iv) BARIMung-5, (v) BINAMung-2; and three spacings of planting viz. (i) $30 \mathrm{~cm} \times 10 \mathrm{~cm}$, (ii) $20 \mathrm{~cm} \times 20 \mathrm{~cm}$ and (iii) $40 \mathrm{~cm} \times 30 \mathrm{~cm}$. The experiment was laid out in a randomized complete block design with three replications. Size of each unit plot was $3 \mathrm{~m} \times 2 \mathrm{~m}$. Experimental land was prepared with ploughing and laddering and was uniformly fertilized with $20 \mathrm{~kg} \mathrm{~N}, 40 \mathrm{~kg} \mathrm{P}_{2} \mathrm{O}_{5}$ and $20 \mathrm{~kg} \mathrm{~K}_{2} \mathrm{O}$ $\mathrm{ha}^{-1}$ through urea, triple super phosphate (TSP) and muriate of potash (MP), respectively at final land preparation (BARI, 1999). Crop management practices such as weeding, thinning and plant protection measures were done as per requirement. Data on yield attributes were taken from 5 randomly selected plants plot $^{-1}$. The crops of $3 \mathrm{~m}^{2}(3 \mathrm{~m} \times 1 \mathrm{~m})$ in each plot were harvested by hand picking of pods at different dates as per maturity of different varieties. Seed yield was recorded at $10 \%$ moisture content. The collected data were compiled and tabulated properly for statistical analysis. Analysis of variance was done with the help of computer package M-STAT program and differences among treatment means were tested with Duncan's Multiple Range Test (DMRT) (Gomez and Gomez, 1984).

\section{Results and Discussion}

\section{Yield contributing characters and yield}

\section{Effect of variety}

Five varieties of mungbean differed significantly for plant height (Table 1). Variety BARIMung2 and BARIMung-4 produced statistically identical and the highest plant height followed in order by BINAMung-2 and BARIMung-3. The lowest plant height $(32.67 \mathrm{~cm})$ was observed in BARIMung-5. Variation in plant height of varieties might have occurred due to their differences in genetic make-up.

Variety BARIMung-2 produced the highest dry matter plant $^{-1}$ followed in order by BARIMung-3, BINAMung-2, BARIMung-4 and BARIMung-5. The variety BARIMung-5 produced the lowest dry matter plant ${ }^{-1}$ (Table1). Less number of branches plant $^{-1}$ and less plant height were mainly responsible for the lowest dry matter production.

Variety BARIMung-2 and BARIMung-3 produced the highest and statistically identical number of branches plant ${ }^{-1}$ while BINAMung-2 and BARIMung-4 occupied the second position. The lowest number of branches plant ${ }^{-1}$ was observed in BARIMung-5. Variety BARIMung-2 and BARIMung-5 produced the highest and statistically identical number of pods branch ${ }^{-1}$. The lowest number of pods branch $^{-1}$ was produced in BARIMung-3, which was statistically identical to BARIMung-4 and BINAMung-2. The highest number of pods plant ${ }^{-1}$ was produced in the variety BARIMung-2 and the lowest in BARI-Mung-3. Varieties BARIMung-4, BARIMung-5 and BINAMung-2 were statistically identical to BARIMung-3 in this respect. The highest length of pod was found in the variety BARIMung-5. The lowest pod length was found in BARIMung-2, which was statistically identical to the rest three varieties (Table 1). Variety BARIMung-5 produced the highest number of seeds pods ${ }^{-1}$, which was similar to BARIMung2. The lowest number of seeds pod ${ }^{-1}$ was produced in BARIMung-4. Varity BARIMung-3 and BINAMung-2 were statistically identical to BARIMung-4 in this regard. BARIMung-5 produced the highest 1000-seed weight followed in order by BINAMung-2, BARIMung-2, BARIMung-3 and BARIMung-4. Variation in 1000-seed weight among the varieties of mungbean might be due to their different genetic characteristics. Similar trend of performance in 1000-seed weight was observed in Mungbean by Samanta et al. (1999). 
Significant variation in seed yield was observed among five varieties of mungbean (Table1). Variety BARIMung-2 gave the highest seed yield $\left(843.7 \mathrm{~kg} \mathrm{ha}^{-1}\right)$. The high yield potential of BARIMung-2 was realized mainly through increased number of branches plant ${ }^{-1}$, number of pods branch ${ }^{-1}$, number of pods plant ${ }^{-1}$ and seeds $\operatorname{pod}^{-1}$ (Table 1$)$. The second highest seed yield was observed in BARIMung-3, which was statistically identical to those observed in BARIMung-4 and BARIMung-5. The lowest seed yield was obtained in BINAMung-2.

Table 1. Effects of variety and plant spacing on yield contributing characters and yield of mungbean

\begin{tabular}{|c|c|c|c|c|c|c|c|c|c|c|c|}
\hline Treatment & $\begin{array}{l}\text { Plant } \\
\text { height } \\
(\mathrm{cm})\end{array}$ & $\begin{array}{l}\text { Total dry } \\
\text { matter } \\
\text { at harvest } \\
\text { (g plant }^{-1} \text { ) }\end{array}$ & $\begin{array}{c}\text { Number of } \\
\text { branches } \\
\text { plant }^{-1}\end{array}$ & $\begin{array}{l}\text { Number } \\
\text { of pods } \\
\text { branch-1 }\end{array}$ & $\begin{array}{c}\text { Number } \\
\text { of pods } \\
\text { plant }^{-1}\end{array}$ & $\begin{array}{c}\text { Pod } \\
\text { length } \\
(\mathrm{cm})\end{array}$ & $\begin{array}{c}\text { Number } \\
\text { of seeds } \\
\text { pod }^{-1}\end{array}$ & $\begin{array}{l}\text { Weight } \\
\text { of } 1000 \\
\text { seeds } \\
(\mathrm{g})\end{array}$ & $\begin{array}{c}\text { Seed } \\
\text { yield } \\
\left(\mathrm{kg} \mathrm{ha}^{-1}\right)\end{array}$ & $\begin{array}{c}\text { Stover } \\
\text { yield } \\
\left(\mathrm{kg} \mathrm{ha}^{-1}\right)\end{array}$ & $\begin{array}{c}\text { Harvest } \\
\text { Index } \\
(\%)\end{array}$ \\
\hline BARIMung-2 & $38.12^{\mathrm{ab}}$ & $10.57^{a}$ & $2.22^{a}$ & $3.67^{a}$ & $14.56^{\mathrm{a}}$ & $6.79^{b}$ & $10.33^{\mathrm{ab}}$ & $30.89^{c}$ & $843.70^{a}$ & $1850^{b}$ & $31.38^{a}$ \\
\hline BARIMung-3 & $36.18^{c}$ & $9.94^{b}$ & $2.11^{a b}$ & $3.14^{b}$ & $11.56^{b}$ & $6.84^{b}$ & $9.78^{b c}$ & $30.73^{d}$ & $783.80^{b}$ & $1800^{b}$ & $29.19^{b}$ \\
\hline BINAMung-2 & $36.94^{b c}$ & $8.91^{c}$ & $1.92^{\mathrm{bc}}$ & $3.28^{b}$ & $11.56^{b}$ & $6.87^{b}$ & $9.53^{c}$ & $31.13^{b}$ & $701.20^{c}$ & $1990^{\mathrm{ab}}$ & $26.16^{c}$ \\
\hline$S \bar{x}$ & 0.403 & 0.08 & 0.06 & 0.06 & 0.265 & 0.028 & 0.146 & 0.036 & 3.695 & 54.0 & 0.195 \\
\hline Level of significance & 0.01 & 0.01 & 0.01 & 0.01 & 0.01 & 0.01 & 0.01 & 0.01 & 0.01 & 0.01 & 0.01 \\
\hline \multicolumn{12}{|l|}{ Spacing of planting } \\
\hline $20 \mathrm{~cm} \times 20 \mathrm{~cm}$ & $34.69^{c}$ & $8.79^{b}$ & $1.57^{c}$ & $3.62^{\mathrm{a}}$ & $12.00^{b}$ & $6.86^{\mathrm{b}}$ & 9.77 & $31.38^{c}$ & $750.50^{\mathrm{b}}$ & $1840^{b}$ & $29.28^{a}$ \\
\hline Level of significance & 0.01 & 0.01 & 0.01 & 0.01 & 0.01 & 0.01 & NS & 0.01 & 0.01 & 0.01 & 0.01 \\
\hline CV $(\%)$ & 3.30 & 2.62 & 9.49 & 5.48 & 6.49 & 1.18 & 4.40 & 0.34 & 1.43 & 8.31 & 2.04 \\
\hline
\end{tabular}

Means having same letter(s) in a column do not differ significantly (as per DMRT). NS= Not significant

Stover yield was significantly affected by varieties (Table1). The highest stover yield was obtained in BARIMung-4 mainly due to the highest plant height (Table 1). BINAMung-2 was statistically identical to BARIMung-4 regarding stover yield. The lowest stover yield was obtained in BARIMung-3, which was statistically identical to BARIMung-2 and BARIMung-5. Harvest index was significantly affected by varieties (Table1). The highest harvest index was obtained in variety BARIMung-2 mainly due to the highest seed yield (Table1) followed in order by BARIMung-3 and BARIMung-5. The lowest harvest index was observed in BINAMung-2, which was statistically identical to that of BARIMung-4.

\section{Effect of plant spacing}

All yield contributing characters were significantly influenced by planting density except number of seeds $\operatorname{pod}^{-1}$ (Table 1 ). The tallest plant was observed at a planting density of 40 $\mathrm{cm} \times 30 \mathrm{~cm}$ mainly due to more space for growing up the individual plant. The shortest plant was observed at a planting density of $20 \mathrm{~cm} \times 20 \mathrm{~cm}$. The highest dry matter plant ${ }^{-1}$ was produced at spacing of $30 \mathrm{~cm} \times 10 \mathrm{~cm}$, which was identical to that of $40 \mathrm{~cm} \times 30 \mathrm{~cm}$. The lowest dry matter plant ${ }^{-1}$ was produced in $20 \mathrm{~cm} \times 20 \mathrm{~cm}$ spacing. The highest number of branches plant $^{-1}$ was observed at $30 \mathrm{~cm} \times 10 \mathrm{~cm}$ spacing followed in order by $40 \mathrm{~cm} \times 30 \mathrm{~cm}$ and $20 \mathrm{~cm} \times 20 \mathrm{~cm}$. The highest number of pods branch $^{-1}$ was produced at $20 \mathrm{~cm} \times 20 \mathrm{~cm}$ spacing and the lowest number of pods branch ${ }^{-1}$ was produced at $40 \mathrm{~cm} \times 30 \mathrm{~cm}$ spacing, which was similar to $30 \mathrm{~cm} \times 10 \mathrm{~cm}$ spacing. The highest number of pods plant ${ }^{-1}$ was found at $30 \mathrm{~cm} \times 10 \mathrm{~cm}$ spacing and the lowest one was found at $40 \mathrm{~cm} \times 30 \mathrm{~cm}$. However, $20 \mathrm{~cm}$ $\times 20 \mathrm{~cm}$ spacing produced similar pods plant ${ }^{-1}$ as that of $40 \mathrm{~cm} \times 30 \mathrm{~cm}$ spacing. The highest pod length was observed at $30 \mathrm{~cm} \times 10 \mathrm{~cm}$ spacing. The lowest pod length was observed at 
$20 \mathrm{~cm} \times 20 \mathrm{~cm}$ spacing, which was statistically identical to $40 \mathrm{~cm} \times 30 \mathrm{~cm}$ spacing. The highest 1000 -seed weight was observed at $40 \mathrm{~cm} \times 30 \mathrm{~cm}$ spacing followed in order by 30 $\mathrm{cm} \times 10 \mathrm{~cm}$ and $20 \mathrm{~cm} \times 20 \mathrm{~cm}$ spacing.

The highest seed yield $\left(1046.0 \mathrm{~kg} \mathrm{ha}^{-1}\right)$ was obtained at $30 \mathrm{~cm} \times 10 \mathrm{~cm}$ spacing followed in order by $20 \mathrm{~cm} \times 20 \mathrm{~cm}$ and $40 \mathrm{~cm} \times 30 \mathrm{~cm}$ spacing. This highest seed yield resulted mainly due to higher number of branches plant ${ }^{-1}$ and number of pods plant ${ }^{-1}$ (Table 1 ).

The highest stover yield was observed at $30 \mathrm{~cm} \times 10 \mathrm{~cm}$ spacing mainly due to higher number of branches plant ${ }^{-1}$ and the lowest one was observed at $40 \mathrm{~cm} \times 30 \mathrm{~cm}$ spacing. The highest harvest index was found at $20 \mathrm{~cm} \times 20 \mathrm{~cm}$ spacing and the lowest harvest index was found at $40 \mathrm{~cm} \times 30 \mathrm{~cm}$ spacing. The harvest index at $30 \mathrm{~cm} \times 10 \mathrm{~cm}$ was statistically identical to that of $40 \mathrm{~cm} \times 30 \mathrm{~cm}$ spacing.

\section{Interaction effects of variety and spacing of planting}

Interaction effects between variety and spacing of planting were significant in all yield contributing characters except number of seeds $\operatorname{pod}^{-1}$ (Table 2). The highest plant height was observed in BARIMung-4 planted at a spacing of $40 \mathrm{~cm} \times 30 \mathrm{~cm}$ and the lowest plant height was observed in BARIMung-5 planted at a spacing of $20 \mathrm{~cm} \times 20 \mathrm{~cm}$. The variety BARIMung-2 planted at a spacing of $30 \mathrm{~cm} \times 10 \mathrm{~cm}$ produced the highest dry matter plant ${ }^{-1}$, which was identical to that of BARIMung-3. The lowest dry matter plant ${ }^{-1}$ was produced in BARIMung-4 planted at a spacing of $20 \mathrm{~cm} \times 20 \mathrm{~cm}$, which was statistically identical to BARIMung-5 and BINAMung-2 at the same spacing (Table 2). The highest number of branches plant ${ }^{-1}$ was observed in BARIMung-2 planted at a spacing of $30 \mathrm{~cm} \times 10 \mathrm{~cm}$, which was statistically identical to BARIMung-3 at the same spacing. The lowest number of branches plant ${ }^{-1}$ was observed in variety BARIMung-5 planted at $20 \mathrm{~cm} \times 20 \mathrm{~cm}$ spacing. The highest number of pods branch ${ }^{-1}$ was observed in variety BARIMung-2 at $30 \mathrm{~cm} \times 10 \mathrm{~cm}$ spacing, which was statistically identical to BARIMung-5, BARIMung-2 and BARIMung-4 at $20 \mathrm{~cm} \times 20 \mathrm{~cm}$ spacing, BARIMung-5 at $30 \mathrm{~cm} \times 10 \mathrm{~cm}$ and BINAMung-2 at $40 \mathrm{~cm} \times 30 \mathrm{~cm}$ spacing. The lowest number of pods branch ${ }^{-1}$ was found in BINAMung-2 at spacing of $30 \mathrm{~cm}$ $\times 10 \mathrm{~cm}$. The highest number of pods plant ${ }^{-1}$ was observed in variety BARIMung-2 planted at a spacing of $30 \mathrm{~cm} \times 10 \mathrm{~cm}$ (Table 2) and the lowest number of pods plant ${ }^{-1}$ was observed in variety BARIMung-2 and variety BINAMung-2 planted at a spacing of $40 \mathrm{~cm} \times 30 \mathrm{~cm}$ and BARIMung-3 planted at a spacing of $20 \mathrm{~cm} \times 20 \mathrm{~cm}$. The highest pod length was observed in BARIMung-5 planted at spacings of $20 \mathrm{~cm} \times 20 \mathrm{~cm}$ and $30 \mathrm{~cm} \times 10 \mathrm{~cm}$ and the lowest pod length was observed in BARIMung-2 planted at $40 \mathrm{~cm} \times 30 \mathrm{~cm}$ spacing. The highest 1000 seed weight was observed in BARIMung-5 at $40 \mathrm{~cm} \times 30 \mathrm{~cm}$ spacing due to longer and heavier seed size (Table 2) and the lowest 1000-seed weight was observed in BARIMung-2 planted at $40 \mathrm{~cm} \times 30 \mathrm{~cm}$ spacing and in BARIMung-4 planted at $20 \mathrm{~cm} \times 20 \mathrm{~cm}$ spacing, which were statistically identical (Table 2).

The variety BARIMung-2 planted at a spacing of $30 \mathrm{~cm} \times 10 \mathrm{~cm}$ gave the highest seed yield $\left(1217.0 \mathrm{~kg} \mathrm{ha}^{-1}\right)$ due to the highest number of pods produced plant $^{-1}$. The second highest seed yield was obtained in variety BARIMung-3 planted at a spacing of $30 \mathrm{~cm} \times 10 \mathrm{~cm}$. The lowest seed yield was obtained in BARIMung-3 at $40 \mathrm{~cm} \times 30 \mathrm{~cm}$ spacing, which was statistically identical to that of BARIMung-2 at the same spacing (Table 2).

All the varieties planted at a density of $30 \mathrm{~cm} \times 10 \mathrm{~cm}$ produced the highest and statistically identical stover yield. Higher stover yields were obtained mainly due to higher number of branches plant ${ }^{-1}$ and pods plant ${ }^{-1}$ (Table 2). The lowest stover yield was observed in variety BARIMung-2 planted at a spacing of $40 \mathrm{~cm} \times 30 \mathrm{~cm}$. 
Table 2. Interaction effects of variety and plant spacing on yield contributing characters and yield of mungbean

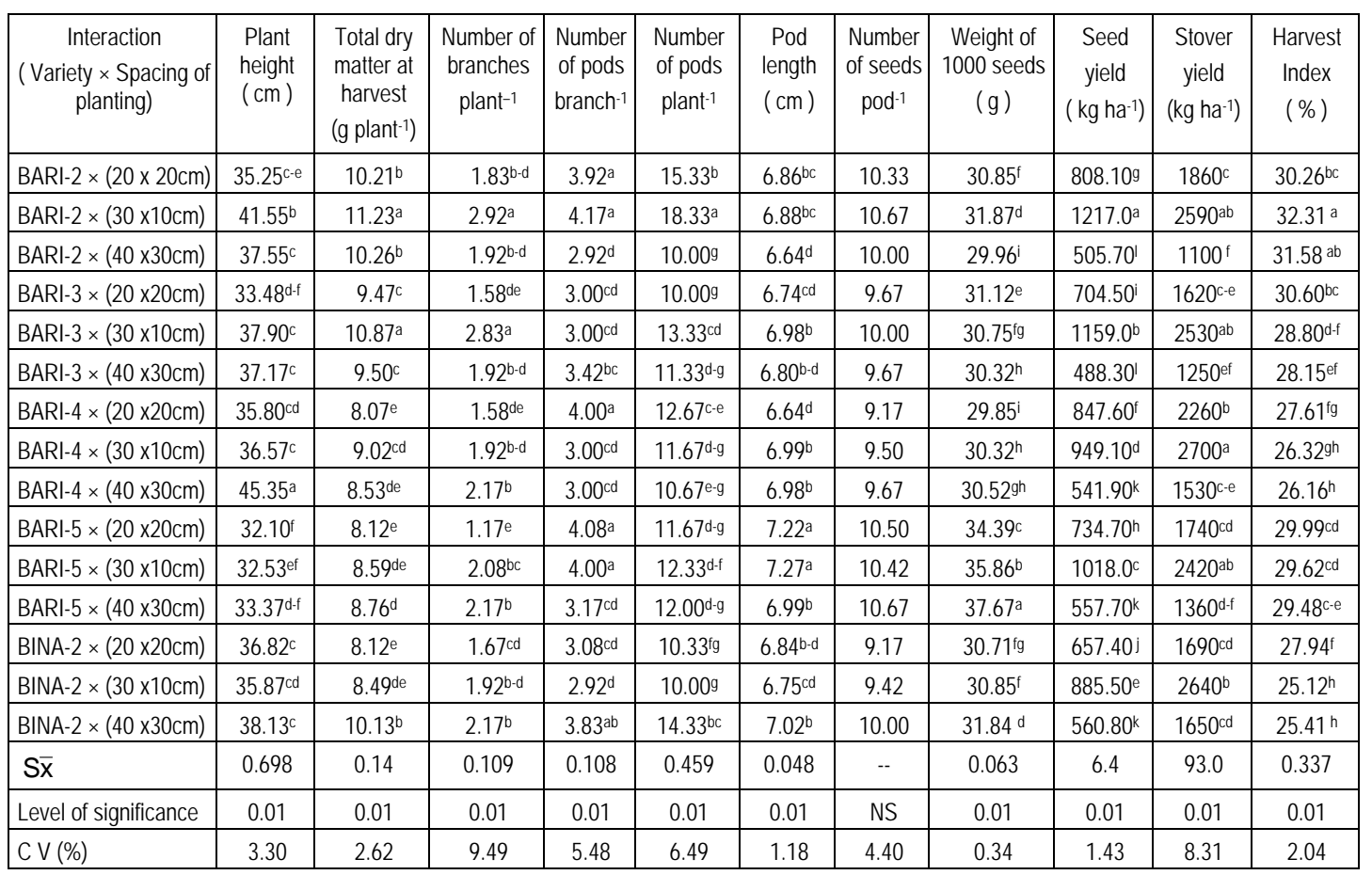

Means having same letter(s) in a column do not differ significantly as per DMRT. NS= Not significant.

The highest harvest index was obtained in the variety BARIMung-2 planted at a spacing of 30 $\mathrm{cm} \times 10 \mathrm{~cm}$ mainly due to the highest seed yield (Table 2). Similar harvest index was obtained from the variety BARIMung-2 planted at a spacing of $40 \mathrm{~cm} \times 30 \mathrm{~cm}$. The lowest harvest indices were obtained from the varieties BARIMung-4 and BINAMung-2 planted at a spacing of $40 \mathrm{~cm} \times 30 \mathrm{~cm}$ and the variety BINAMung-2 planted at a spacing of $30 \mathrm{~cm} \times 10 \mathrm{~cm}$ (Table 2).

From the present study it is concluded that $30 \mathrm{~cm} \times 10 \mathrm{~cm}$ plant spacing was more suitable for the cultivation of mungbean variety BARIMung-2 in Kharif-I season. Variety BARIMung-5 produced the highest weight of 1000 seeds and the longest pods, but not the seed yield.

\section{Acknowledgement}

The authors thankfully acknowledge the financial assistance of the Ministry of Science and Information and Communication Technology, Government of the People's Republic of Bangladesh to carry out this research.

\section{References}

Ahmed, Z.U., Shaikh, M.A.Q. and Razzaque, M.A. 1987. Bangladesh Assoc. Advan. Sci. Dhaka (Bangladesh) In: Proc. 12th Ann. Bangladesh Sci. Conf., Section 1, Dhaka (Bangladesh), BAAS. p. 13.

BARI (Bangladesh Agricultural Research Institute). 1997. Report of lentil, blackgram and mungbean development pilot project. Pulse Res. Sta., Bangladesh Agril. Res. Inst., Joydebpur, Gazipur.1701, Bangladesh. pp. 24-25. 
BARI (Bangladesh Agricultural Research Institute). 1998. Bangladesh-e Moog Daler Chash (in Bangla)-Mungbean Cultivation in Bangladesh. Pulse Res. Sta., Bangladesh Agril. Res. Inst., Joydebpur, Gazipur-1701, Bangladesh. p. 45

BARI (Bangladesh Agricultural Research Institute).1999. Krishi Projukti Hat Boi (in Bangla)-Handbook on Agrotechnology. Rashid et al. (Eds.). Bangladesh Agril. Res. Inst., Joydebpur, Gazipur-1701, Bangladesh. p. 100 .

Gomez, K.A. and Gomez, A.A. 1984. Statistical Procedure for Agricultural Research. 2nd Edn., John Wiley and Sons., New York. pp. 207-215.

Haque, M.M. 1995. Effect of plant population on the growth and yield of mungbean. Bangladesh J. Sci. Ind. Res., 3(1): 63-69.

ICRISAT (International Crop Research Institute for Semi-Arid Tropics).1991. Prospects of increasing pulses production through improved cropping systems. Adv. Pulses Res. Bangladesh. Intl. Crops Res. Inst. SemiArid Tropics, Hydrabad, India. p. 66.

Kabir, M.H. 2001. Krishitattik Gobeshona (in Bangla)- (Agronomic Research). Textbook Division, Bangla Academy, Dhaka-1000. Bangladesh. p. 400.

Mimber, S.M. 1993. Influence of plant density and plant population per hill on growth and yield of mungbean. Agrivita., 16(2): 78-82.

Samanta, S.C., Faruk-E-Azam, A.K.M. and Rashid, M.H. 1999. Effects of sowing dates on grain yield, protein and mineral contents of five mungbean cultivars. Thai. J. Agric. Sci., 32(2): 171-177.

Thakuria, A. and Saharia, P. 1997. Response of mungbean (Vigna radiata L. Wilczek) genotypes to plant density and phosphorus levels in summer. Indian J. Agron., 35(4): 431-432. 